\title{
PERAN GEL LIDAH BUAYA DALAM MENGURANGI XEROSIS
}

\author{
Fatimah Khoirini
}

\author{
Politeknik Kesehatan Kementerian Kesehatan Bengkulu, Jurusan Keperawatan, \\ Jalan Indragiri Nomor 03 Padang Harapan Kota Bengkulu \\ jmkbengkulu@gmail.com
}

\begin{abstract}
The management of patients with Chronic Renal Failure (CRF) is the immediate treatment of the infection to prevent infection to the patient's kidney due to decreased immunity. CRF patients almost all have dermatological disorders, including xerosis. Pharmacological treatment causes a lot of side effects. One natural ingredient is aloe vera. Aloe vera as a moisturizer, antibiotics and as well itching. This study aims to analyze the effectiveness of aloe vera gel as a material alternative to nursing implementations in xerosis CRF patients in Semarang hospitals. This type of research is experiment with using pretest posttest control group design, selection sampling with random sampling taking random table. The number of respondents 36 people, that are 18 people giving the control group a placebo gel skin lotion 2 times daily after bath for 3 days and 18 people experimental group with the administration of aloe gel 2 times daily after bath for 3 days. Observations using Akhyani modifications observation sheet. Xerosis difference in the two groups were analyzed by paired samples T-test, while the relationship with the respondent characteristics xerosis is analyzed by independent sample T-test and corelations. Statistical test results showed no significant difference xerosis before and after administration of aloe vera gel with xerosis value $(\mathrm{p}=$ 0.000). The implication of this study is the Aloe vera gel can be considered to be alternatives to nursing implementations xerosis patients with CRF.
\end{abstract}

Keywords : Aloe vera gel, xerosis

\begin{abstract}
Abstrak: Penatalaksanaan pasien Gagal Ginjal Kronik (GGK) yaitu pengobatan segera terhadap infeksi untuk mencegah infeksi sampai ke ginjal karena pasien mengalami penurunan imunitas. Pasien GGK hampir semua memiliki gangguan dermatologis, diantaranya xerosis. Penanganan farmakologis banyak menimbulkan efek samping, untuk menghindari hal tersebut maka digunakan salah satu bahan alami yaitu lidah buaya. Lidah buaya digunakan sebagai pelembab, antibiotik dan mengatasi rasa gatal. Penelitian ini bertujuan untuk menganalisa efektifitas gel lidah buaya sebagai bahan alternatif tindakan keperawatan pada xerosis penderita GGK. Jenis penelitian ini adalah Eksperimen menggunakan pre test post test control group design, tehnik pengambilan sampel dengan random sampling. Jumlah responden 36 orang yaitu : 18 orang kelompok kontrol pemberian lotion kulit gel placebo 2 kali sehari setelah mandi selama 3 hari dan 18 orang kelompok eksperimen dengan pemberian gel lidah buaya 2 kali sehari setelah mandi selama 3 hari. Observasi menggunakan lembar observasi modifikasi Akhyani. Dianalisis dengan uji paired sample T-test. Hasil Uji statistik menunjukkan ada perbedaan bermakna xerosis sebelum dan sesudah pemberian gel lidah buaya dengan nilai xerosis $(\mathrm{p}=0.000)$. Implikasi dari penelitian ini adalah Gel lidah buaya bisa dipertimbangkan menjadi bahan alternatif tindakan keperawatan pada xerosis penderita GGK.
\end{abstract}

Kata kunci : Gel lidah buaya, Xerosis

Pasien dengan penyakit ginjal stadium lanjut hampir semua memiliki minimal satu gangguan dermatologis (Linde, 2007). Manifestasi kulit paling umum timbul pada penyakit ginjal stadium lanjut diantaranya xerosis. Xerosis yaitu gambaran kulit kering atau kasar terjadi pada $50-70 \%$ pasien dialisa. Xerosis dimanifestasikan dengan sedikitnya turgor kulit, kulit kering, pecah-pecah khususnya permukaan ekstremitas. Kondisi ini dapat membuat sangat tidak nyaman karena menyebabkan bertambahnya celah di kulit, 
ulcer, iritasi, dermatitis kontak ataupun alergi. Hal ini juga predisposisi terhadap infeksi karena membahayakan pertahanan kulit normal. Tertundanya penyembuhan luka pada pasien penyakit ginjal stadium lanjut ini meningkatkan risiko infeksi (Linde, 2007). Salah satu penatalaksanaan pasien Gagal Ginjal Kronik (GGK) yaitu pengobatan segera terhadap infeksi untuk mencegah infeksi sampai keginjal karena pada penderita GGK terjadi penurunan imunitas (Stahle dalam Halim, 2012).

Xerosis disebabkan berkurangnya kelembaban akibat hilangnya lipid dan faktor pelembab alami di stratum corneum. Xerosis ditandai dengan gejala kekeringan pada permukaan kulit yang menjadi bersisik, keras dan rasa tidak nyaman (Draelos dalam Pray, 2006). Kondisi yang berkelanjutan akan menyebabkan permukaan kulit retak dan pecah-pecah yang berakibat timbulnya iritasi dan inflamasi. Xerosis dapat menimbulkan masalah yang cukup serius bila tidak ditangani sejak dini. Jika kedalaman pecahan tersebut cukup dalam hingga lapisan dermis akan menimbulkan perdarahan yang memicu infeksi oleh jamur dan bakteri (Bauman dalam Pray, 2006).

Banyak penelitian menyebutkan daun lidah buaya dapat sebagai anti inflamasi, anti jamur, anti bakteri dan regenerasi sel (Furnawanthi, 2002). Telah diteliti oleh Atik (2007) tanaman lidah buaya dapat digunakan untuk perawatan luka, penelitian oleh Wijaya (2013) lidah buaya dapat digunakan untuk luka bakar, penelitian oleh Tjahayani (2007) lidah buaya dapat digunakan pada luka rongga mulut. Serta penelitian Rajin (2008) didapatkan bahwa pemberian kompres lidah buaya dapat menurunkan tingkat phlebitis pada 8 jam ketiga setelah pemberian kompres. Penelitian eksperimenal laboratoris oleh Hidayah (2006) menyimpulkan penggunaan gel aloe vera tidak toksik terhadap sel fibroblast sehingga aman untuk digunakan dalam rongga mulut.

Lidah buaya dapat digunakan untuk pengobatan luar untuk beberapa kondisi kulit seperti ekszema, luka dan luka bakar. Lidah buaya juga bisa digunakan sebagai pengurang nyeri dan peradangan. Lidah buaya juga dapat digunakan sebagai antiseptik dan antibiotik (Rajeswari, 2012).

Lidah buaya ini menghasilkan 6 agent antiseptik seperti lupeol, salicylic acid, urea nitrogen, cinnamonic acid, phenol dan sulphur. Semua subtansi ini tergolong antiseptik karena dapat membunuh kuman atau mengontrol pembentukan bakteri jamur dan virus (Rajeswari, 2012). Lidah buaya menghambat migrasi sel PMN (neutrophil) ke jaringan vena yang meradang, sehingga proses inflamasi vena dihambat. Kandungan asam amino, glikoprotein dan aloe emodin dalam lidah buaya mempercepat perkembangan sel-sel baru dalam proses regenerasi epitel pembuluh darah (Rajin, 2008).

Gel lidah buaya dapat melembabkan kulit karena mengandung air yang banyak (West, 2003). Gel lidah buaya mempunyai kadar air tinggi yaitu 94,83\% (Ramadhia, 2012). Penelitian oleh Schulz mengatakan gel lidah buaya mengandung air 99\% dan yang lainnya glucomanans, asam amino, lipid, sterol dan vitamin (Schulz, 2014). Mucopolysakarida membantu dalam mengikat kelembaban kulit. Lidah buaya menstimulasi fibroblast yang menghasilkan kolagen dan serat elastis yang membuat kulit lebih elastis dan mengurangi kerutan. Asam amino di dalam lidah buaya juga mengurangi kulit yang kasar dan zink bertindak sebagai astringent untuk mempererat pori-pori kulit juga mempunyai efek anti jerawat (West, 2003).

Lidah buaya mengandung zat aktif lignin yang mempunyai kemampuan penyerapan tinggi sehingga memudahkan peresapan gel ke dalam kulit atau mukosa (Furnawanthi, 2002). Menurut Kumar biasanya lidah buaya digunakan sebagai pelembab, penelitian menunjukkan lidah buaya efektif mengurangi kekeringan pada kulit, membersihkan jerawat, alergi pada kulit, noda kehitaman dan kulit yang berwarna tidak rata dan membuat kulit menjadi cerah (Kumar, 2010).

Sabun yang mengandung lidah buaya juga telah diteliti oleh Olsen dapat me- 
nurunkan insiden reaksi kulit pada pasien dengan kemoterapi (Olsen, 2001).

Pada penelitian tentang uji racun dan fungsi hati terhadap penggunaan lidah buaya oleh Sultana di dapatkan hal sebagai berikut : tidak terdapat kejadian kematian hewan uji selama total periode eksperimen, terdapat peningkatan bilirubin total yang signifikan pada hewan uji coba yang mendapat aloe vera, terdapat penurunan Bilirubin direct, SGPT, $\gamma$ GT, alkalin phospat dan SGOT yang signifikan selama 30 hari pemberian aloe vera (Sultana, 2012). Lidah buaya mempunyai efek hepatoprotektif (Saleh, 2008).

Menurut Ramachandraiagari perbandingan hasil histologi ginjal mencit diabetes yang diberi ekstrak lidah buaya terdapat perbaikan epitel pada tubulus sedangkan pada yang tidak diberi lidah buaya terdapat kerusakan glomerulus yang komplit serta pembesaran tubulus.

Aktifitas Superoxide dismutase (SOD), Catalase (CAT), Glutathione peroxidase (GPx) dan Glutathione reductase (GR) meningkat didalam jaringan hati dan ginjal mencit diabetes pada pemberian ekstrak lidah buaya (Ramachandraiahgari, 2012).

Pada penelitian pemeriksaan histologi jaringan ginjal mencit yang mengalami diabetes oleh Bolkent terdapat regenerasi jaringan epitel tubulus ginjal yang signifikan setelah pemberian glibenclamid dan ekstrak lidah buaya. Walaupun pada masing-masing individu berbeda, tikus yang diberi gel lidah buaya regenerasinya lebih baik sehingga jaringan ginjal yang rusak akibat diabetes lebih sedikit dibanding yang hanya mendapatkan glibenclamid saja dengan penurunan derajat kerusakan jaringan ginjal berubah dari kerusakan sedang menjadi kerusakan derajat rendah. Juga ditemukan ekstra lidah buaya dapat mengurangi level urea dan kreatinin (Bolkent, 2004).

Hasil penelitian Chatterjee mengungkapkan gel ekstrak lidah buaya mempunyai efek perlindungan yang sangat signifikan terhadap cisplatin dan gentamicin yang berakibat neprotoxic, ini mengindikasikan bahwa ekstrak lidah buaya mempunyai efek nefroprotektif yang signifikan (Chatterjee, 2012).

Penelitian ini bertujuan untuk menganalisa efektifitas gel lidah buaya sebagai bahan alternatif tindakan keperawatan pada xerosis penderita GGK

\section{BAHAN DAN CARA KERJA}

Penelitian ini menggunakan desain eksperimen dengan menggunakan pre test post test control group design. Pada penelitian ini sampel dibagi dalam dua kelompok yaitu satu kelompok perlakuan dengan gel lidah buaya dan satu kelompok kontrol dengan placebo Carboxyl Methyl Cellulosa (CMC).

Populasi pada penelitian ini adalah seluruh pasien Gagal Ginjal Kronik yang menjalani terapi Hemodialisa di Rumah Sakit Umum Daerah Kota Semarang pada bulan oktober tahun 2015 berjumlah 75 orang. Jumlah minimal sampel pada penelitian ini adalah 15 subyek per kelompok ditambah kemungkinan drop out $20 \%$ sehingga menjadi 18 orang per group. Sampel yang diambil adalah yang memenuhi persyaratan penelitian Kriteria inklusi: Pasien GGK yang berobat pada saat penelitian bulan Oktober 2015, mengalami xerosis, tidak masuk dalam kriteria penurunan kesadaran, kooperatif, bersedia menjadi responden dan mengikuti tata cara penelitian. Kriteria eksklusi: menggunakan gel atau obat-obatan yang bertujuan mencegah atau mengatasi xerosis dan pruritus, serta memiliki alergi sediaan atau hasil pemeriksaan patch test positif.

Pada penelitian ini cara merandom subyek dengan menggunakan tabel angka random.Intrumen yang digunakan adalah lembar observasi tentang xerosis pada kulit pasien GGK berdasarkan modifikasi.

\section{HASIL}

\section{Gambaran xerosis sebelum intervensi}

Keluhan xerosis dinilai sebelum pemberian gel. Hasil penelitian menunjukkan bahwa xerosis sebelum intervensi pada kelompok eksperimen didapatkan rata-rata 6 
dan kelompok kontrol didapatkan xerosis rata-rata adalah 5,5. Hasil statistik menunjukkan bahwa skor xerosis pada masingmasing kelompok sebelum dilakukan pengolesan gel adalah setara ( $\mathrm{p}$ value 0.279 $>\alpha=0.05$ ).

Tabel. 1. Gambaran kesetaraan xerosis sebelum dilakukan intervensi

\begin{tabular}{cccc}
\hline & $\begin{array}{c}\text { kontrol } \\
(\mathbf{n = 1 8})\end{array}$ & $\begin{array}{c}\text { eksperimen } \\
(\mathbf{n = 1 8})\end{array}$ & p value \\
\hline $\begin{array}{c}\text { Skor xerosis } \\
\text { Pre ntervensi } \\
\text { mean (SD) }\end{array}$ & $5.5(1.4)$ & $6.0(1.0)$ & 0.279 \\
\hline
\end{tabular}

Pengaruh pemberian gel lidah buaya dan gel placebo terhadap xerosis pasien Gagal Ginjal Kronik

Grafik 1. Gambar perubahan nilai xerosis sebelum dan setelah di berikan intervensi gel lidah buaya dan gel placebo pada pasien GGK

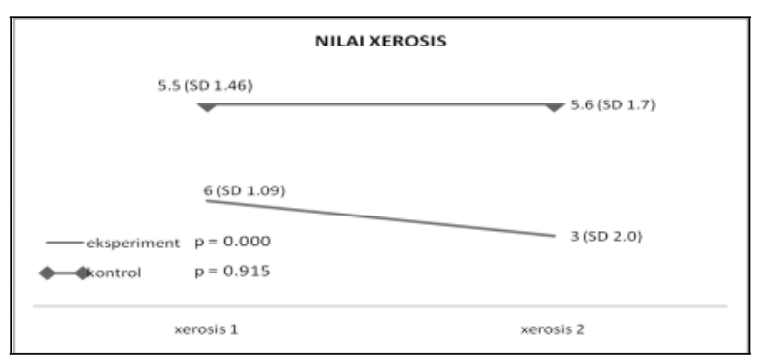

SD,standar deviasi

*Statistik signifikan (nilai p) diperoleh melalui uji t

Pengaruh gel placebo terhadap xerosis kelompok kontrol Berdasarkan hasil penelitian pada kelompok kontrol didapatkan hasil nilai mean xerosis sebelum intervensi 5.5 dan setelah intervensi nilai mean xerosis 5.6 Setelah di uji dengan uji $t$ dependen didapatkan hasil nilai xerosis ( $p$ value 0.915 $>\alpha=0.05)$. Berdasarkan statistik ini diketahui nilai $p>\alpha=0.05$ sehingga dapat disimpulkan tidak ada perbedaan yang signifikan nilai xerosis sebelum dan sesudah pemberian gel placebo.

Pada kelompok eksperimen didapatkan nilai mean xerosis sebelum intervensi 6.0 dan setelah intervensi nilai mean xerosis 3.0 setelah di uji dengan uji $t$ dependen didapat hasil nilai xerosis ( $p$ value $0.000<\alpha=0.05$ ) Sehingga dapat disimpulkan ada perbedaan yang signifikan nilai xerosis sebelum dan sesudah pemberian gel lidah buaya selama 3 hari pada kelompok eksperimen.
Pada kelompok eksperimen didapatkan nilai mean pruritus sebelum intervensi 6.3 dan nilai mean pruritus setelah intervensi 4.8 setelah di uji dengan uji $t$ dependen didapat hasil nilai pruritus ( $\mathrm{p}$ value $0.000<\alpha=0.05$ ). Sehingga dapat disimpulkan ada perbedaan yang signifikan nilai pruritus sebelum dan sesudah pemberian gel lidah buaya selama 3 hari pada kelompok eksperimen.

\section{PEMBAHASAN}

Gel lidah buaya dapat menurunkan keluhan xerosis karena gel lidah buaya dapat melembabkan kulit karena kandungan air yang tinggi dalam lidah buaya berdasarkan penelitian Ramadhia (2012) kandungan air dalam lidah buaya yaitu 94,83\%. Kandungan air dapat membuat kulit menjadi lembab hal ini sesuai dengan penelitian Okada tahun 2004 yang berjudul effect of skin care with an emollient containing a high water content on mild uremic pruritus. Emollient adalah sejenis pelembab berbahan dasar lipid dari tumbuhan dan hewan atau minyak mineral atau sintetik yang kandungan airnya $80 \%$. Pada penelitian Okada ini didapatkan penurunan pruritus yang signifikan disertai penurunan kekeringan kulit pada kelompok yang menggunakan emollient (Okada, 2004).

Pada keadaan normal, air mengalir secara difusi dari dermis menuju ke epidermis melalui dua cara yaitu melalui stratum corneum dan ruang interseluler. Oleh sebab itu normal air akan keluar dari tubuh melalui epidermis, keadaan tersebut dikenal dengan istilah transepidermal water loss (TEWL). Proses difusi pasif terjadi karena terdapatnya perbedaan kandungan air dari stratum basalis $(60-70 \%)$, stratum granulosum (40$60 \%$ ) dan stratum corneum kurang dari $15 \%$ sehingga air mengalir dari stratum basalis ke stratum corneum. Dengan demikian maka stratum corneum merupakan barier hidrasi yang sangat penting dalam memepertahankan kelembaban kulit. Pada kulit yang sakit (terdapat kelainan epidermis), barier kulit melemah sehingga kecepatan TEWL meningkat 10 kali lebih besar dari normal. 
Dengan tingginya kandungan air dalam lidah buaya membantu mensuplai kebutuhan air pada kulit yang mengalami penurunan fungsi (Purwandhani, 2008).

Selain kandungan air yang tinggi pada lidah buaya zat lain yang diduga dapat membantu proses penurunan keluhan xerosis yaitu zat lignin, mucopolisakarida, asam amino dan zink. Lidah buaya mengandung zat aktif lignin yang mempunyai kemampuan penyerapan tinggi sehingga memudahkan peresapan gel ke dalam kulit atau mukosa (Hart, 1990). Mucopolysakarida membantu dalam mengikat kelembaban kulit sehingga air tertahan didalam lapisan kulit, serta menstimulasi fibroblast yang menghasilkan kolagen dan serat elastis yang membuat kulit lebih elastis dan mengurangi kerutan. Kandungan lidah buaya yang lainnya adalah Asam amino yang berfungsi mengurangi kulit yang kasar serta zink bertindak sebagai astringent untuk mempererat pori-pori kulit (West, 2003).

\section{DAFTAR RUJUKAN}

Atik N, Januarsih Iwan A.R. 2007 Perbedaan efek pemberian topical gel lidah buaya dengan solusion pavidon iodine terhadap penyembuhan luka sayat pada kulit mencit. (Thesis)

Baumann L. 2002. Cosmetic dermatology: principles and practice. The McGraw-hill. Companies. New York. dalam Pray W.S.and Pray J.J. 2006. Managing Dry Skin. US Pharmacist.

Bolkent S, Akev N, Ozsoy N, Inceli MS, Can A, Okyar A, Yanardag R. 2004. Effect of aloe vera leaf gel and pulp ekstracs on kidney in tipe-II diabetic rat. Indian Journal of experimental biology.

Chatterjee P, Muherjee A, Nandy S. 2012. Protective effects of the aqueous leaf extract of aloe barbadensis on gentamicin and cisplatin induced nefrotoxic rats. Asian Pacific journal of tropical Biomedicine.

Draelos Z.D.2000. Dermatologic aspects of cosmetic : Therapeutic moisturizers. Dermatol Clin. dalam Pray W.S.and Pray J.J. Managing Dry Skin.2006. US Pharmacist.

Furnawanthi. 2002. Khasiat dan manfaat lidah buaya.cetakan 1. Jakarta. Argo Media Pustaka.

Hart LA, Nibbering PH, Van Den Bars ellar MT, Van Dijik H, Labadei RP. 1990. Effects of molecular constituents from aloe vera gel on
Lidah buaya bukan hanya dapat mengurangi kekeringan pada kulit pasien GGK tapi Sabun yang mengandung lidah buaya juga telah diteliti oleh Olsen dapat menurunkan insiden reaksi kulit pada pasien dengan kemoterapi (Olsen, 2001). Penelitian invitro Tanaka tahun 2015 tentang pemberian $40 \mu \mathrm{g}$ aloe sterol secara oral setiap hari selama 2 minggu menunjukkan menurunnya kerutan kulit wajah pada wanita jepang yang berumur $\geq 40$ tahun karena aloe vera merangsang colagen dan hyaluronic acid yang diproduksi oleh dermal fibroblast (Tanaka, 2015).

\section{KESIMPULAN}

Pada peneltian ini berdasarkan penyebab implikasi dari penelitian ini adalah Gel lidah buaya bisa dipertimbangkan menjadi bahan alternatif tindakan keperawatan pada xerosis penderita GGK.

oxidative metabolism and cytotoxic and bactericidal activities of human neutrophils. Int Journal Immunopharmacol.

Hidayah B. 2006. Uji toksisitas aloe vera berbagai kosentrasi terhadap sel fibroblast. Fakultas kedokteran gigi Unair.

Kumar K.P.S, Debjit B, Chiranjib, Biswijit. 2010. Aloe vera a potential herb and its medicinal importance. J.Chem.Pharm. Res.

Kuypers DRJ. 2009. Skin problem in cronic kidney disease. Medscap.

Lynde C and John K.2007. Skin manifestations of kidney disease conditions range from benign to life-threatening.

Mettang T, Weisshaar E. 2010. Pruritus : Control of itch in patient undergoing dialysis.

Okada K, Matsumoto K. 2004. Effect of skin care with an emollient containing a high water content on mild uremic pruritus. Ther apherdial.

Olsen SL, Raub W Jr, Brandley C, Johnson M, Macias JL, Love V, Markoe A. 2001.The effect of aloe vera gel/mild soap versus mild soap alone in preventing skin reactions in patients undergoing radiation therapy. Oncol Nurs Forum.

Purwandhani E, Effendi EHF. 2000. Pelembab dan emolien untuk kelainan kulit pada bayi dan anak. MDVI vol 27 no 4 september 2000 dalam Donna partogi.2008 : kulit kering. 
Rajeswari R, Umadevi M, Sharmila RC, Pushpa R, Selvavenkhades S, Sampath Kumar KP, Debjid B. 2012. aloe vera the miracle plant its medicinal and traditional uses in india.

Rajin M, Indah M. 2008. Pemamfaatan kompres ekstra lidah buaya pada pasien phlebitis untuk mengurangi biaya di rumah sakit. (Thesis).

Ramachandraiahgari RMY, Somesula SR, Adi PJ, Mannur IS, Enamala M, Matcha B. 2012. Protective role of ethanolic ekstrak of aloe vera antioxidant properties on liver and kidney of stertozotocin induced diabetic rat. Digest journal of nanomaterials and biostructures

Ramadhia M. 2012. pembuatan tepung lidah buaya dengan metode foam - mat drying. (Thesis).

Ro J.Y, Lee B.C, Kim J.Y, Chung Y.J, Chung M.H, Lee S.K, Jo T.H, Kim K.H, Park

Saleh I, Alqasaumi, Tawfiq A, Al Howiriny and Majed S, Abdel Hirsute. 2008. Curcumis prophatarum and bee propolis against experimentally induced liver injury in rats. Int J. Pharmacol.

Schulz V, Hansel R, Tyler VE. 1997. Rational phytoterapy: a physician guide to herbal medicine.Berlin:springer. dalam Senan P.
2014. Aloe vera : a miracle plant with biological actions. World Journal of Pharmacy and Pharmaceutical science.

Sultana N, Rahila N. 2012. gross toxicities and hepatoprotektif effect of aloe vera (L) burm.f.International Research J. Of Pharmacy.

Tanaka M, Misawa E, Yamauchi K, Abe F, Ishizaki C, 2015. Effects of plant sterolderived from aloe vera gel on human dermal fibroblast in vitro and on skin condition in japanese women. Clint cosmet investig dermatol.

West DP, Zhu Y. 2003. evaluation of aloe vera gel gloves in the treatment of dry skin associated with occpruritusational exposure. Am J Infect Control.

Wijaya A.R. 2013 Formulasi krim ekstrak lidah buaya sebagai alternatif penyembuh luka bakar.(Thesis)

Y.I. 2000. Inhibitory mechanism of aloe single component (Alprogen) on mediator release in guinea pig lung mast cells activated with specific antigen-antibody reactions. Journal of pharmacology and experimental therapeutic. 